\title{
Stability of Seed Yield and its Components in some Alfalfa Genotypes Under Different Environments
}

\author{
Bakheit, B.R. ; M.Z. El-Hifny ${ }^{1}$; M.S. Hassan ${ }^{2}$ and Abdalrady, W.A. ${ }^{2}$ \\ ${ }^{1}$ Agronomy Department, Faculty of Agriculture, Assiut University \\ 2 Agronomy Department, Faculty of Agriculture, South Valley University \\ Received on: 14/9/2017 \\ Accepted for publication on: 12/10/2017
}

\section{Abstract}

This investigation was carried out to study the effect of temperature resulting from different sowing dates during the stage of flowering and seed maturity as well as the effect of genotypes $\mathrm{x}$ environment interaction on seed yield and its components in some populations of alfalfa (Medicago sativa L.). A set of six populations from Egypt and one Genan from U.S.A. (Aswan, Balady, Dakha, Ismailia-1, Nitrogen fixed and Siwa) were sown on three sowing dates i.e. $20^{\text {th }}$ of each of October, November and December in randomized complete block design with three replicates in the experimental farm of South Valley University during 2014/2015 and 2015/2016 seasons. Three cuts were taken after 80, 125 and 165 days from sowing.

The results revealed that the highest number of pods/plant (63.8), 1000 seed weight $(2.77 \mathrm{~g})$ and seed yield/plant $(0.86 \mathrm{~g})$ were obtained from sowing on the $20^{\text {th }}$ November. This result is due to that seed production is taking place during the April month.

The Aswan population outyielded $\left(134.8 \mathrm{~g} / \mathrm{m}^{2}\right)$ other tested populations. On the other hand, Genan U.S.A. population gave the lowest yield $\left(51.2 \mathrm{~g} / \mathrm{m}^{2}\right)$ over all sowing dates and seasons. Moreover, the environments, populations and their interaction were signficiant for number of pods/plant, number of seeds/pod, 1000 seed weight and seed yield.

The estimates of genotypic stability parameters ( $\alpha$ and $\lambda$ ) for seed yield and its components showed that the average stability region involved Ismailia-1 population for number or pods/plant; Balady, Ismailia-1 and Nitrogen fixed populations for number of seeds/pod; Ismailia-1 for 1000 seed weight and Nitrogen fixed for seed yield $/ \mathrm{m}^{2}$.

Also, the results showed that Aswan population was the highest seed yielding, but exhibited less stability (instable in seed yield). In contrast, Nitrogen fixed population showed lower seed yield, but in stable region.

Keywords: Alfalfa, Medicago sativa L., Sowing date, Stability, Genotype x environment interaction, Seed yield and its components.

\section{Introduction}

Alfalfa or lucerne (Medicago sativa L.), which is called "The Queen of Forges" is one of the most important forage crops in terms of total area, economic value and energy efficiency. Alfalfa is a highly palatable forage crop containing high pro- tein, calcium and vitamins and low cellulose (Ghanizadeh et al., 2014). Alfalfa remains in the land, on which it has been cultivated about 4 to 10 years with regrowth habit after any time of riping. Due to its deep, strong and perennial root system, alfalfa protects soil, reduces soil erosion, 
improves water penetration, and contributes to growth of soils useful micro-organisms (Rezaei et al., 2010). In addition, due to its high growth vigour, along with annual harvesting, it facilitates weeds control during the growth period (Maarten, 2001).

In alfalfa farm, in compare to other crops, rate of using herbicides is very low and almost approaches zero.

Current changes in the climatic conditions towards warming especially in Egypt are expected to prolong the summer season and shortens the winter season and extended in temperature during which alfalfa in grown. Thus, it was though desirable to change the planting date of alfalfa to avoid the high temperature effects at the beginning of the fall season.

Alfalfa seed production has always been almost low, and thus a little interest has been shown towards its production (Kowithayakorn \& Hill, 1982). Seed yield are usually under severe influence of environmental conditions, genetic characteristics and agricultural techniques (Iannucci and Martiniello, 1998 and Sengul, 2006). Few researches have been conducted on the effect of temperature resulting from different, sowing dates and the effect of genotype $\mathrm{x}$ environment interaction on seed yield production of alfalfa. With this respect Huyghe et al. (2001) found that the genetic variance for seed yield was large but the cultivar $\mathrm{x}$ environment variance was small. Also, Bolaños-Aguilar et al. (2002) found large variation in seed yield among cultivars and environments.

The cultivar $\mathrm{x}$ environment interaction was significant. No information is available in Egypt regarding the influence of temperature resulting from different sowing dates and the effect of genotype $x$ environment interaction on seed yield production of alfalfa.

Regarding to low yield of seed producing farms and no information in Egypt with this respect, this research was conducted to study the effect of temperature conditions resulting from different sowing dates on the seed yield and its components, as well as to study the stability of seed yield of alfalfa varieties when tested under different environments (sowing dates $\mathrm{x}$ seasons).

\section{Materials and Methods}

The present study was carried out at the Agronomy Department Experimental Farm, Faculty of Agriculture, South Valley University, Qena, Egypt, during two successive growing seasons of 2014/2015 and $2015 / 2016$ to study the effect of temperature conditions resulting from different sowing dates on seed yield and its components of seven alfalfa varieties. The physical and chemical properties of the experimental soil in $2014 / 2015$ and 2015/2016 seasons are sand $(82,85 \%)$, silt $(8,11 \%)$, clay $(10,4 \%)$, soil $\mathrm{pH}(7.7,8)$ organic matter $(0.17,0.15 \%)$, total $\mathrm{N} \mathrm{mg} / \mathrm{kg}$ $(198,34)$ and $\mathrm{CaCO}_{3}(8.5,9.7 \%)$, respectively.

The genetic materials for this study included six varieties from Egypt i.e. Aswan, Balady, El-Dakhla, Ismailia-1, Nitrogen fixed, and Siwa and Genan variety from U.S.A.

Three sowing dates of $20^{\text {th }}$ October (D1), $20^{\text {th }}$ November (D2) and $20^{\text {th }}$ December (D3) were used for the seven alfalfa varieties in randomized complete block design with three rep- 
lications in both seasons. Plot size was one meter square ( 3 meter long $\mathrm{x}$ $0.33 \mathrm{~m}$ apart). Alfalfa seed were sown by hand at the rate of $10.0 \mathrm{~g} / \mathrm{m}^{2}$. Phosphorus was applied at level of 4 g $\mathrm{P}_{2} \mathrm{O}_{5} /$ plot in the form of calcium super phosphate $\left(\mathrm{P}_{2} \mathrm{O}_{5} 15.5 \%\right)$ before seeding. All cultural practices were maintained at optimum level for maximum alfalfa productivity. Three cuts were taken from each sowing date at 80,125 and 165 days after sowing. After three cuts from each sowing date, the crop was left for flowering and seed production in the first week of each of April, May and June for each sowing date, respectively, in the two seasons.

\section{Table 1. Summary of daily temperature during the period of alfalfa growth in} 2014/2015 and 2015/2016 seasons

\begin{tabular}{|c|c|c|c|c|c|c|c|c|c|c|c|c|c|c|c|c|c|c|c|}
\hline \multirow{3}{*}{\multicolumn{2}{|c|}{$\begin{array}{l}\text { Weather } \\
\text { factor }\end{array}$}} & \multicolumn{6}{|c|}{ Average temperature ${ }^{\circ} \mathrm{C}$} & \multicolumn{6}{|c|}{ Average relative humidity $\%$} & \multicolumn{6}{|c|}{ Sun shine } \\
\hline & & \multicolumn{3}{|c|}{$2014 / 2015$} & \multicolumn{3}{|c|}{ 2015/2016 } & \multicolumn{3}{|c|}{$2014 / 2015$} & \multicolumn{3}{|c|}{$2015 / 2016$} & \multicolumn{3}{|c|}{$2014 / 2015$} & \multicolumn{3}{|c|}{$2015 / 2016$} \\
\hline & & Max. & Min. & Mean & Max. & Min. & Mean & Max. & Min. & Mean & Max. & Min. & Mean & $\begin{array}{l}\text { Sun } \\
\text { rise }\end{array}$ & $\begin{array}{c}\text { Sun } \\
\text { set }\end{array}$ & $\begin{array}{c}\text { Day } \\
\text { length }\end{array}$ & $\begin{array}{l}\text { Sun } \\
\text { rise }\end{array}$ & $\begin{array}{c}\text { Sun } \\
\text { set }\end{array}$ & $\begin{array}{c}\text { Day } \\
\text { length }\end{array}$ \\
\hline Oct. & 20-31 & 32.12 & 17.65 & 24.88 & 33.64 & 21.19 & 27.42 & 51.00 & 16.42 & 33.71 & 57.25 & 22.25 & 39.75 & $5: 45$ & $17: 13$ & $11: 28$ & $5: 45$ & $17: 13$ & $11: 28$ \\
\hline \multirow{3}{*}{ Nov. } & 01-10 & 32.07 & 17.33 & 24.70 & 28.63 & 16.49 & 26.68 & 50.17 & 16.08 & 33.13 & 57.58 & 22.50 & 40.04 & $5: 45$ & $17: 12$ & $11: 26$ & $5: 45$ & $17: 12$ & $11: 26$ \\
\hline & $11-20$ & 32.24 & 17.26 & 24.75 & 28.33 & 16.45 & 26.10 & 48.33 & 15.25 & 31.79 & 57.75 & 22.33 & 40.04 & $5: 49$ & $17: 11$ & 11:21 & $5: 51$ & 17:11 & 11:19 \\
\hline & 21-30 & 32.41 & 17.21 & 24.81 & 28.46 & 16.22 & 25.57 & 47.92 & 14.58 & 31.25 & 60.33 & 23.50 & 41.92 & $5: 54$ & $17: 10$ & $11: 16$ & $5: 54$ & $17: 10$ & $11: 16$ \\
\hline \multirow{3}{*}{ Dec. } & 01-10 & 32.13 & 17.07 & 24.60 & 23.73 & 15.94 & 24.98 & 47.58 & 14.83 & 31.21 & 62.75 & 25.00 & 43.88 & $5: 54$ & 17:09 & $11: 14$ & $5: 54$ & 17:09 & $11: 14$ \\
\hline & $11-20$ & 31.66 & 17.03 & 24.34 & 21.56 & 15.50 & 24.14 & 49.00 & 15.33 & 32.17 & 64.92 & 26.08 & 45.50 & $5: 55$ & 17:09 & 11:13 & $5: 55$ & $17: 09$ & 11:13 \\
\hline & 21-31 & 31.38 & 16.83 & 24.11 & 22.39 & 15.42 & 23.32 & 50.92 & 16.00 & 33.46 & 65.33 & 25.92 & 45.63 & $5: 56$ & $17: 08$ & $11: 12$ & $5: 56$ & 17:08 & $11: 12$ \\
\hline \multirow{3}{*}{ Jan. } & 01-10 & 31.21 & 16.56 & 23.88 & 21.50 & 15.74 & 22.88 & 52.50 & 16.92 & 34.71 & 63.92 & 26.25 & 45.08 & $5: 56$ & $17: 07$ & $11: 10$ & $5: 56$ & 17:07 & $11: 10$ \\
\hline & $11-20$ & 31.06 & 16.50 & 23.78 & 22.31 & 15.97 & 22.65 & 53.00 & 17.25 & 35.13 & 64.83 & 26.58 & 45.71 & $5: 57$ & $17: 07$ & 11:09 & $5: 57$ & 17:07 & 11:09 \\
\hline & 21-31 & 31.21 & 16.59 & 23.90 & 18.29 & 15.76 & 22.54 & 52.75 & 17.50 & 35.13 & 64.83 & 26.00 & 45.42 & $5: 58$ & $17: 06$ & 11:08 & $5: 58$ & 17:06 & $11: 08$ \\
\hline \multirow{3}{*}{ Feb. } & 01-10 & 31.25 & 16.53 & 23.89 & 23.07 & 15.49 & 22.50 & 51.83 & 17.75 & 34.79 & 65.00 & 26.08 & 45.54 & $5: 58$ & $17: 05$ & $11: 07$ & $5: 58$ & $17: 05$ & $11: 07$ \\
\hline & $11-10$ & 31.37 & 16.56 & 23.96 & 29.65 & 15.09 & 22.43 & 51.92 & 18.33 & 35.13 & 66.50 & 26.33 & 46.42 & $5: 59$ & $17: 05$ & 11:06 & $5: 59$ & $17: 05$ & 11:06 \\
\hline & 21-29 & 31.28 & 16.51 & 23.89 & 26.38 & 14.83 & 22.35 & 52.92 & 19.25 & 36.08 & 67.00 & 26.33 & 46.67 & 6:00 & $17: 05$ & $11: 05$ & 6:00 & 17:05 & $11: 05$ \\
\hline \multirow{3}{*}{ Mar. } & 01-10 & 31.12 & 16.24 & 23.68 & 30.85 & 14.72 & 22.28 & 56.08 & 19.75 & 37.92 & 67.33 & 26.42 & 46.88 & $6: 00$ & $17: 04$ & $11: 03$ & $6: 00$ & $17: 04$ & 11:03 \\
\hline & $11-20$ & 30.86 & 15.87 & 23.36 & 30.49 & 14.57 & 22.14 & 57.83 & 20.75 & 39.29 & 67.08 & 26.67 & 46.88 & $6: 01$ & $17: 04$ & $11: 02$ & $6: 01$ & $17: 04$ & 11:02 \\
\hline & 21-31 & 30.67 & 15.75 & 23.21 & 30.50 & 14.35 & 22.10 & 59.17 & 20.92 & 40.04 & 64.17 & 25.83 & 45.00 & 6:02 & 17:03 & 11:01 & $6: 02$ & 17:03 & 11:01 \\
\hline \multirow{3}{*}{ Apr. } & 01-10 & 30.51 & 15.78 & 23.14 & 35.25 & 14.25 & 22.15 & 60.17 & 21.42 & 40.79 & 63.42 & 25.08 & 44.25 & 6:02 & 17:02 & 11:00 & 6:02 & $17: 02$ & $11: 00$ \\
\hline & $11-20$ & 30.48 & 15.58 & 23.03 & 34.64 & 13.67 & 22.15 & 59.92 & 21.75 & 40.83 & 62.58 & 25.08 & 43.83 & $6: 03$ & $17: 02$ & $10: 58$ & $6: 03$ & 17:02 & $10: 58$ \\
\hline & 21-30 & 30.28 & 15.58 & 22.93 & 39.07 & 13.53 & 22.04 & 60.00 & 22.25 & 41.13 & 63.42 & 25.00 & 44.21 & 6:04 & $17: 02$ & $10: 57$ & 6:04 & $17: 02$ & $10: 57$ \\
\hline \multirow{3}{*}{ May } & $01-10$ & 29.99 & 15.48 & 22.74 & 37.94 & 13.73 & 21.93 & 61.42 & 23.00 & 42.21 & 64.00 & 25.00 & 44.50 & 6:04 & $17: 01$ & $10: 56$ & 6:04 & $17: 01$ & $10: 56$ \\
\hline & $11-20$ & 29.72 & 15.18 & 22.45 & 41.21 & 13.86 & 21.81 & 64.08 & 23.67 & 43.88 & 64.50 & 24.67 & 44.58 & $6: 05$ & 17:01 & $10: 55$ & $6: 05$ & 17:01 & $10: 55$ \\
\hline & 21-31 & 29.23 & 14.93 & 22.08 & 37.40 & 13.93 & 21.58 & 68.17 & 24.42 & 46.29 & 64.00 & 25.00 & 44.50 & $6: 05$ & $17: 00$ & $10: 55$ & $6: 05$ & $17: 00$ & $10: 55$ \\
\hline \multirow{3}{*}{ Jun. } & 01-10 & 28.77 & 14.59 & 21.68 & 44.53 & 14.00 & 21.42 & 70.25 & 24.42 & 47.33 & 64.83 & 25.50 & 45.17 & 6:06 & $17: 00$ & $10: 54$ & 6:06 & $17: 00$ & $10: 54$ \\
\hline & $11-20$ & 28.22 & 14.31 & 21.26 & 42.03 & 13.75 & 21.30 & 70.17 & 24.58 & 47.38 & 66.50 & 26.00 & 46.25 & 6:07 & $16: 59$ & $10: 52$ & 6:07 & 16:59 & $10: 52$ \\
\hline & 21-30 & 27.69 & 13.98 & 20.84 & 42.16 & 13.40 & 21.22 & 69.83 & 24.67 & 47.25 & 68.00 & 26.00 & 47.00 & 6:07 & $16: 59$ & $10: 51$ & 6:07 & 16:59 & $10: 51$ \\
\hline \multirow{3}{*}{ Jul. } & 01-10 & 27.22 & 13.71 & 20.46 & 40.69 & 13.32 & 21.18 & 68.17 & 25.25 & 46.71 & 68.42 & 27.08 & 47.75 & 6:08 & $16: 59$ & $10: 50$ & 6:08 & 16:59 & $10: 50$ \\
\hline & $11-20$ & 26.76 & 13.61 & 20.18 & 40.68 & 12.90 & 21.05 & 70.17 & 25.50 & 47.83 & 69.17 & 27.83 & 48.50 & 6:09 & $16: 59$ & $10: 49$ & 6:09 & 16:59 & $10: 49$ \\
\hline & 21-31 & 26.24 & 13.14 & 19.69 & 40.53 & 12.57 & 21.03 & 70.17 & 26.17 & 48.17 & 70.92 & 28.00 & 49.46 & 6:09 & $16: 58$ & $10: 48$ & 6:09 & $16: 58$ & $10: 48$ \\
\hline
\end{tabular}

Source: Meteorological authority, Qena, Egypt 


\section{Data recorded:}

After seed maturity stage, the plots for seed yield and its components were harvested and the following traits were recorded:

1- Number of pods/plant: A random sample of ten plants had taken from each plot. The average number of pods/plant had recorded.

2- Number of seeds/pod (as the average of 500 pods).

3- 1000 seed weight (seed index, g): From each plot, five samples each of 1000 seeds had weighted. The average of 1000-seeds weight was recorded.

4- Seed yield/plant (g): A random sample of ten plants had taken from each plot at seed maturity stage. The average of seed yield/plant was recorded.
5- Seed yield/plot $\left(\mathrm{g} / \mathrm{m}^{2}\right)$ determined from each plot, plants had harvested at seed maturity stage, where, manually threshed.

Climatic data during the study period including maximum and minimum daily temperature, relative humidity and photoperiod measured from planting date to date of physiological maturity in each season and planting date (Table 1).

The total growing degree days (GDD), (base $=7^{\circ} \mathrm{C}$ ) was calculated according to Saeed and Francis (1984) as follows:

Total growing degree days $(\mathrm{GDD})=$ $\Sigma[(($ Maximum + Minimum temperature)/2)-7]

Where $7=$ Zero growth point from sowing date to maturity, (Table 2).

Table 2. Total growing degree days (GDD) for each planting date and season at Qena where alfalfa trials were conducted.

\begin{tabular}{|l|c|c|c|c|}
\hline \multirow{2}{*}{ Sowing date } & \multicolumn{2}{c|}{$\begin{array}{c}\text { Forage yield from sowing date } \\
\text { until third cut }\end{array}$} & \multicolumn{2}{c|}{$\begin{array}{c}\text { Seed yield after the third cut } \\
\text { until seed maturity }\end{array}$} \\
\cline { 2 - 5 } & $\mathbf{2 0 1 4 / 2 0 1 5}$ & $\mathbf{2 0 1 5 / 2 0 1 6}$ & $\mathbf{2 0 1 4 / 2 0 1 5}$ & $\mathbf{2 0 1 5 / 2 0 1 6}$ \\
\hline $20^{\text {th }}$ October & 2038 & 2017 & 1008 & 1406 \\
\hline $20^{\text {th }}$ November & 2041 & 2127 & 1246 & 1615 \\
\hline $20^{\text {th }}$ December & 2143 & 2528 & 1569 & 1695 \\
\hline
\end{tabular}

Separate as well as combined analyses of variance were performed for the data over the two seasons according to Gomez and Gomez (1984), whenever the homogeneity of variances between sowing dates were detected. Means were compared using R.L.S.D. test at 5\% level of probability.

Stability analysis was computed according to Tai (1971), where he suggested partitioning the genotype $\mathrm{x}$ environment interaction (GE) effect of the $i^{\text {th }}$ genotypes into two components $\left(\alpha_{\mathrm{i}}\right.$ and $\left.\lambda_{\mathrm{i}}\right)$. These estimates $\left(\alpha_{\mathrm{i}}\right.$ and $\lambda_{\mathrm{i}}$ ) were computed for each variety under the three sowing dates in the two seasons (6 environments) to compare the relative stability of varieties. The parameter $\alpha_{i}$ measures the linear response to the environmental effect and $\lambda_{i}$ parameter measures the deviation from linear response in terms of the magnitude of the error variance. The two components are defined as genotypic stability parameters. The values $(\alpha=-1, \lambda=1)$ will be referred as perfect stability. However, the values $(\alpha=0, \lambda=1)$ will be referred as average stability, whereas 
the values $(\alpha>0$ and $\lambda=1)$ as below average stability. The hyperbola graph to test $\alpha$ 's statistics and the limits of the confidence interval for $\lambda$ 's statistics were superimposed according to Tai (1971).

\section{Results and Discussion}

\section{I- Performance of varieties under different sowing dates:}

\section{I.1- Number of pods/plant:}

The number of pods/plant is one of the components in determining the seed yield.

The combined analysis of variance for number of pods/plant over the two seasons is shown in Table 3. The results showed highly significant differences between, seasons, sowing dates and varieties for the number of pods/plant. In addition to the highly significant interactions effects were observed, i.e. sowing dates $\mathrm{x}$ seasons, sowing dates $\mathrm{x}$ varieties, varieties $\mathrm{x}$ seasons and sowing dates $\mathrm{x}$ varieties $\mathrm{x}$ seasons for number of pods/plant. This may be due to the large differences in climatic conditions prevailing in these sowing dates and sea- sons. The presence of these interactions suggested a differential response of varieties to various sowing dates.

The average number of pods/plant in 2014/2015, 2015/2016 seasons and over the two seasons as affected by sowing dates and varieties are presented in Table 4.

The highest number of pods/plant of 64.09 and 63.5 were obtained from plants sown at November $20^{\text {th }}$ in 2014/2015 and 2015/2016 seasons, respectively. The difference between the two seasons for number of pods/plant may be due to the different climatic conditions [temperature, relative humidity and sunshine (Table 1)]. Over the two seasons comparisons, among the number of pods/plant of the different sowing dates showed that this trait decreased as sowing date was delayed (December $20^{\text {th }}$ ). On the other hand, it is clear that the plants sown at the December $20^{\text {th }}$ produced the lowest number of pods/plant of 54.8 over both seasons.

Table 3. Combined analysis of variance for seed yield and its components of seven alfalfa varieties under three different sowing dates over the two seasons.

\begin{tabular}{|c|c|c|c|c|c|c|}
\hline \multirow{2}{*}{$\begin{array}{l}\text { Source of } \\
\text { variation }\end{array}$} & \multirow[b]{2}{*}{ d.f } & \multicolumn{5}{|c|}{ Mean Square } \\
\hline & & $\begin{array}{l}\text { Number of } \\
\text { pods/plant }\end{array}$ & $\begin{array}{l}\text { Number of } \\
\text { seeds/pod }\end{array}$ & $\begin{array}{c}1000 \text { seed } \\
\text { weight }\end{array}$ & $\begin{array}{c}\text { Seed yield/ } \\
\text { plant (g) }\end{array}$ & $\begin{array}{c}\text { Seed yield } \\
\left(\mathrm{g} / \mathrm{m}^{2}\right)\end{array}$ \\
\hline Year (Y) & 1 & $1594.5^{* *}$ & $49.87 * *$ & $1.64 * *$ & $1.19^{* *}$ & $68214.6^{* *}$ \\
\hline Error (a) & 4 & 57.32 & 0.31 & 0.01 & 0.03 & 1409.04 \\
\hline Sowing dates (D) & 2 & $600.92 * *$ & $29.85 * *$ & $9.4 * *$ & $0.27 * *$ & $10970.8^{* *}$ \\
\hline$Y \times D$ & 2 & $700.45^{* *}$ & $7.61^{* *}$ & $1.57 * *$ & 0.06 & $1644.6^{* *}$ \\
\hline Error (b) & 8 & 58.43 & 0.92 & 0.05 & 0.04 & 269.0 \\
\hline Varieties (V) & 6 & $475.65^{* *}$ & $8.65 * *$ & $0.33 * *$ & $0.27 * *$ & $17484.7 * *$ \\
\hline V x Y & 6 & $442.25^{* *}$ & 0.91 & $0.23 * *$ & $0.11^{* *}$ & $5235.7 * *$ \\
\hline D x V & 12 & $755.8 * *$ & $4.11 * *$ & 0.04 & $0.19 * *$ & $2213.4 * *$ \\
\hline$Y \times D \times V$ & 12 & $223^{* *}$ & $5.01 * *$ & $0.51 * *$ & $0.09^{* *}$ & $2000.8^{* *}$ \\
\hline Error (c) & 72 & 67.11 & 0.84 & 0.03 & 0.03 & 155.73 \\
\hline
\end{tabular}

\footnotetext{
** Significant at 0.01 level of probability.
} 
Table 4. Mean number of pods/plant for seven alfalfa varieties under each sowing dates in 2014/2015, 2015/2016 and over the two seasons.

\begin{tabular}{|c|c|c|c|c|c|c|c|c|c|}
\hline \multirow{2}{*}{ Season } & \multirow{2}{*}{ Sowing date } & \multicolumn{8}{|c|}{ Populations } \\
\hline & & Aswan & Balady & Dakhla & Ismailia & Nitro-gen Fixed & Genan & Siwa & Mean \\
\hline \multirow{8}{*}{$2014 / 2015$} & D1 & 51.71 & 68.29 & 59.92 & 71.48 & 63.81 & 71.29 & 65.20 & 64.53 \\
\hline & $\mathrm{D} 2$ & 53.18 & 71.47 & 53.81 & 69.62 & 70.43 & 66.76 & 63.52 & 64.09 \\
\hline & D3 & 41.22 & 57.67 & 79.79 & 69.76 & 50.52 & 53.14 & 79.00 & 61.59 \\
\hline & Mean & 48.70 & 65.81 & 64.50 & 70.29 & 61.59 & 63.73 & 69.24 & 63.40 \\
\hline & \begin{tabular}{|l|} 
RLSD 5\% for \\
\end{tabular} & & & & & & & & \\
\hline & \begin{tabular}{|l|} 
Sowing date (D) \\
\end{tabular} & & & & & & & & - \\
\hline & Variety (V) & & & & & & & & 96 \\
\hline & $V \times D$ & & & & & & & 10. & 40 \\
\hline \multirow{8}{*}{$2015 / 2016$} & $\mathrm{D} 1$ & 57.52 & 50.49 & 52.38 & 66.90 & 76.90 & 56.86 & 59.63 & 60.10 \\
\hline & $\mathrm{D} 2$ & 63.86 & 53.73 & 58.76 & 65.96 & 65.43 & 72.14 & 64.53 & 63.49 \\
\hline & D3 & 49.74 & 42.95 & 84.12 & 39.29 & 40.90 & 28.62 & 77.00 & 51.90 \\
\hline & Mean & 57.04 & 49.06 & 65.09 & 57.38 & 61.08 & 52.54 & 67.05 & 58.46 \\
\hline & RLSD 5\% for & & & & & & & & \\
\hline & \begin{tabular}{|l|} 
Sowing date (D) \\
\end{tabular} & & & & & & & & .16 \\
\hline & Variety (V) & & & & & & & & .50 \\
\hline & VXD & & & & & & & 14. & .58 \\
\hline \multirow{8}{*}{$\begin{array}{l}\text { Combined } \\
\text { Over } \\
\text { two seasons }\end{array}$} & $\mathrm{D} 1$ & 54.62 & 59.39 & 56.15 & 69.19 & 70.35 & 64.07 & 62.41 & 62.31 \\
\hline & $\mathrm{D} 2$ & 58.52 & 62.60 & 56.29 & 67.79 & 67.93 & 69.45 & 64.03 & 63.80 \\
\hline & D3 & 45.48 & 50.31 & 81.95 & 54.53 & 45.71 & 40.88 & 78.00 & 54.79 \\
\hline & Mean & 52.87 & 57.43 & 64.80 & 63.83 & 61.33 & 58.14 & 68.17 & 60.93 \\
\hline & RLSD 5\% for & & & & & & & \multirow{2}{*}{\multicolumn{2}{|c|}{4.874}} \\
\hline & Sowing date (D) & \multicolumn{3}{|c|}{3.87} & & & YXD & & \\
\hline & Variety (V) & \multicolumn{3}{|c|}{5.2} & & & $\mathbf{Y} \times \mathbf{V}$ & \multicolumn{2}{|c|}{7.40} \\
\hline & VXD & \multicolumn{3}{|r|}{8.7} & & & YxVxD & \multicolumn{2}{|c|}{14.32} \\
\hline
\end{tabular}

D1 $=$ Sowing date at $20^{\text {th }}$ October. D3 $=$ Sowing date at $20^{\text {th }}$ December.

Comparisons between the number of pods/plant of the seven varieties over all sowing dates, the results revealed that, Siwa population produced the highest number of pods/plant of 68.24, 67.05 and 68.2, in the first and second seasons and over two seasons, respectively.

It was also evident that Siwa and Dakhla populations sown on December $20^{\text {th }}$ in first season (2014/2015) produced the highest number of pods/plant. Moreover, over the two seasons the same populations gave the maximum number of pods/plant of 78.0 and 81.95 , respectively, with sowing at the third date (December $20^{\text {th }}$ ).
D2 $=$ Sowing date at $20^{\text {th }}$ November.

- $\mathrm{F}$ value not significant.

\section{I.2- Number of seeds/pod:}

Number of seeds/pod is one of the essential factors in determining the seed yield.

The combined analysis of variance over the two seasons (Table 3) showed that seasons, sowing dates and varieties had a highly significant influence on the number of seeds/pod. Moreover, the analysis showed that the interactions sowing dates $\mathrm{x}$ seasons, sowing dates $\mathrm{x}$ varieties and sowing dates $\mathrm{x}$ varieties $\mathrm{x}$ seasons had highly significant influence on the number of seeds/pod.

The mean number of seeds/pod in 2014/2015, 2015/2016 and over the two seasons are presented in Ta- 
ble 5. The highest number of seeds/pod (6.93 and 6.23) in the first and second seasons, respectively, were obtained from plants sown on December $20^{\text {th }}$ in both seasons. Meanwhile, the number of seeds/pod was decreased as sowing date was early in November $20^{\text {th }}$ (Table 5).
This may be due to the suitable time in sowing date at December $20^{\text {th }}$ for flowering and pollination which coincide with the activity of pollinators by honey bees may be plays a great role in increasing seed setting by tripping the flowers under Qena Governorate conditions.

Table 5. Mean number of seeds/pod for seven alfalfa varieties under each sowing dates in 2014/2015, 2015/2016 and over the two seasons.

\begin{tabular}{|c|c|c|c|c|c|c|c|c|c|}
\hline \multirow{2}{*}{ Season } & \multirow{2}{*}{ Sowing date } & \multicolumn{8}{|c|}{ Populations } \\
\hline & & Aswan & Balady & Dakhla & Ismailia & \begin{tabular}{|l|} 
Nitro-gen Fixed \\
\end{tabular} & Genan & Siwa & Mean \\
\hline \multirow{8}{*}{$2014 / 2015$} & D1 & 4.00 & 6.93 & 6.28 & 4.98 & \begin{tabular}{|l|}
5.72 \\
\end{tabular} & 8.96 & 9.32 & 6.60 \\
\hline & $\mathrm{D} 2$ & 5.04 & 5.30 & 6.28 & 4.52 & 5.12 & 6.16 & 5.00 & 5.35 \\
\hline & D3 & 5.42 & 7.44 & 8.82 & 7.39 & 7.11 & 6.30 & 6.16 & 6.95 \\
\hline & Mean & 4.82 & 6.56 & 7.13 & 5.63 & 5.99 & 7.14 & 6.83 & 6.30 \\
\hline & RLSD 5\% for & & & & & & & & \\
\hline & Sowing date (D) & & & & & & & & 31 \\
\hline & Variety $(\mathbf{V})$ & & & & & & & & 98 \\
\hline & VXD & & & & & & & & 76 \\
\hline \multirow{8}{*}{$2015 / 2016$} & $\mathrm{D} 1$ & 4.41 & 5.77 & 4.28 & 4.36 & 3.58 & 4.17 & 3.94 & 4.36 \\
\hline & $\mathrm{D} 2$ & 1.93 & 4.94 & 5.50 & 3.64 & 3.62 & 6.90 & 5.16 & 4.53 \\
\hline & D3 & 6.71 & 5.98 & 7.55 & 5.47 & 6.68 & 5.12 & 6.12 & 6.23 \\
\hline & Mean & 4.35 & 5.56 & 5.78 & 4.49 & 4.62 & 5.40 & 5.07 & 5.04 \\
\hline & RLSD 5\% for & & & & & & & & \\
\hline & Sowing date (D) & & & & & & & & 81 \\
\hline & Variety $(\mathbf{V})$ & & & & & & & & 75 \\
\hline & VXD & & & & & & & & 23 \\
\hline \multirow{8}{*}{$\begin{array}{c}\text { Combined } \\
\text { over } \\
\text { Two } \\
\text { seasons }\end{array}$} & $\mathrm{D} 1$ & 4.20 & 6.35 & 5.28 & 4.67 & 4.65 & 6.57 & 6.63 & 5.48 \\
\hline & $\mathrm{D} 2$ & 3.49 & 5.12 & 5.89 & 4.08 & 4.37 & 6.53 & 5.08 & 4.94 \\
\hline & D3 & 6.06 & 6.71 & 8.18 & 6.43 & 6.90 & 5.71 & 6.14 & 6.59 \\
\hline & Mean & 4.58 & 6.06 & 6.45 & 5.06 & 5.31 & 6.27 & 5.95 & 5.67 \\
\hline & \begin{tabular}{|l|} 
RLSD 5\% for \\
\end{tabular} & & & & & & & & \\
\hline & \begin{tabular}{|l|} 
Sowing date (D) \\
\end{tabular} & & & 0.45 & & & $\mathbf{Y X}$ & $\mathbf{D}$ & \\
\hline & Variety $(\mathbf{V})$ & & & 0.56 & & & $Y_{x}$ & $\mathbf{V}$ & 05 \\
\hline & V $x D$ & & & 1.05 & & & $\mathbf{Y x V}$ & $\mathbf{x D}$ & 44 \\
\hline
\end{tabular}

D1 $=$ Sowing date at $20^{\text {th }}$ October.

D3 $=$ Sowing date at $20^{\text {th }}$ December.

D2 $=$ Sowing date at $20^{\text {th }}$ November.

Data in Table 5 show that, Dakhla population significantly produced the highest number of seeds/pod as compared with the other studied varieties in both seasons. Also, comparisons show that Dakhla population gave the highest number of seeds/pod of $8.82,7.55$ and 8.18 when sowing was undertaken on December $20^{\text {th }}$ in $2014 / 2015,2015 / 2016$ and over the two seasons, respectively. dex)

\section{I.3- 1000-seed weight (seed in-}

1000 seed weight is an one of the essential factors in determining the seed yield. 
The combined analysis of variance over the two seasons revealed highly significant differences between sowing dates and varieties for 1000 -seed weight. Moreover, the mean square for sowing dates $\mathrm{x}$ seasons, sowing dates $\mathrm{x}$ varieties, varieties $\mathrm{x}$ seasons and sowing dates $\mathrm{x}$ va- rieties $\mathrm{x}$ seasons interactions were statistically highly significant for the 1000-seed weight (Table 3).

The average of 1000 -seed weight in 2014/2015, 2015/2016 and over the two seasons as affected by sowing dates and varieties are presented in Table 6 .

Table 6. Mean 1000 seed weight for seven alfalfa varieties under each sowing dates in 2014/2015, 2015/2016 and over the two seasons.

\begin{tabular}{|c|c|c|c|c|c|c|c|c|c|}
\hline \multirow{2}{*}{ Season } & \multirow{2}{*}{ Sowing date } & \multicolumn{8}{|c|}{ Populations } \\
\hline & & Aswan & Balady & Dakhla & Ismailia & $\begin{array}{c}\text { Nitro-gen } \\
\text { Fixed }\end{array}$ & Genan & Siwa & Mean \\
\hline \multirow{8}{*}{$2014 / 2015$} & D1 & 2.87 & 2.31 & 2.44 & 2.38 & 2.04 & 1.83 & 1.90 & 2.25 \\
\hline & D2 & 2.48 & 3.30 & 2.69 & 2.53 & 2.10 & 2.71 & 3.29 & 2.73 \\
\hline & D3 & 2.10 & 2.06 & 1.64 & 1.88 & 1.92 & 1.86 & 1.85 & 1.90 \\
\hline & Mean & 2.48 & 2.56 & 2.26 & 2.26 & 2.02 & 2.13 & 2.35 & 2.29 \\
\hline & RLSD 5\% for & & & & & & & & \\
\hline & Sowing date (D) & \multicolumn{8}{|c|}{0.16} \\
\hline & Variety $(\mathbf{V})$ & \multicolumn{8}{|c|}{0.18} \\
\hline & V x D & \multicolumn{8}{|c|}{0.31} \\
\hline \multirow{8}{*}{$2015 / 2016$} & $\mathrm{D} 1$ & 2.77 & 3.10 & 2.61 & 2.84 & 3.06 & 2.95 & 3.12 & 2.92 \\
\hline & D2 & 3.46 & 2.51 & 2.37 & 2.94 & 3.13 & 2.64 & 2.58 & 2.80 \\
\hline & D3 & 2.04 & 1.93 & 1.68 & 1.88 & 1.71 & 1.75 & 1.91 & 1.84 \\
\hline & Mean & 2.76 & 2.51 & 2.22 & 2.55 & 2.63 & 2.45 & 2.54 & 2.52 \\
\hline & RLSD 5\% for & & & & & & & & \\
\hline & Sowing date (D) & \multicolumn{8}{|c|}{0.08} \\
\hline & Variety $(\mathbf{V})$ & \multicolumn{8}{|c|}{0.13} \\
\hline & VXD & \multicolumn{8}{|c|}{0.22} \\
\hline \multirow{8}{*}{$\begin{array}{c}\text { Combined } \\
\text { over two } \\
\text { seasons }\end{array}$} & $\mathrm{D} 1$ & 2.82 & 2.70 & 2.53 & 2.61 & 2.55 & 2.39 & 2.51 & 2.59 \\
\hline & $\mathrm{D} 2$ & 2.97 & 2.90 & 2.53 & 2.74 & 2.62 & 2.68 & 2.94 & 2.77 \\
\hline & D3 & 2.07 & 2.00 & 1.66 & 1.88 & 1.82 & 1.81 & 1.88 & 1.87 \\
\hline & Mean & 2.62 & 2.53 & 2.24 & 2.41 & 2.33 & 2.29 & 2.44 & 2.41 \\
\hline & RLSD 5\% for & & & & & & & & \\
\hline & \begin{tabular}{|l|} 
Sowing date (D) \\
\end{tabular} & & & 0.10 & & & Y X D & & 14 \\
\hline & Variety $(\mathrm{V})$ & & & 0.11 & & & Y X V & & 15 \\
\hline & V $x D$ & & & - & & & $\mathbf{Y x V x D}$ & & 26 \\
\hline
\end{tabular}

D1= Sowing date at $20^{\text {th }}$ October. D3 $=$ Sowing date at $20^{\text {th }}$ December.

It could be revealed that the heaviest 1000 -seed weight were obtained from the plants sown on October $20^{\text {th }}$ in $2014 / 2015,2015 / 2016$ and over the two seasons. The average of 1000 -seed weight for the different sowing dates show that the 1000 -seed weight was decreased as sowing dates
D2 $=$ Sowing date at $20^{\text {th }}$ November.

- F value not significant.

were delayed. It is clear that, plants sown at the third sowing date (December $20^{\text {th }}$ ) produced the lowest 1000 seed weight of $1.90,1.84$ and 1.87 in $2014 / 2015,2015 / 2016$ and over the two seasons, respectively. Comparing between varieties showed that the New Valley and Siwa popu- 
lations produced significant heavier seed than the other used varieties in 1000 -seed weight in 2014/2015 season and over the two seasons (Table 6). On the other hand, the results showed that the New Valley and Siwa populations gave the heaviest 1000 -seed weight when sowing was undertaken on October $20^{\text {th }}$ in first and second seasons and over the two seasons.

\section{I.4- Seed yield/plant (g):}

The combined analysis of variance over the two seasons showed highly significant differences among seasons, sowing dates and populations respect to seed yield/plant (Table 3). Also, highly significant differences were found for populations $\mathrm{x}$ seasons, sowing dates $\mathrm{x}$ populations, and seasons $\mathrm{x}$ populations $\mathrm{x}$ sowing dates interactions. These results indicated that the response of the studied populations under different sowing dates varied from season to other. This results may be due to the large differences in climatic conditions prevailing in these sowing dates (Table 2). The presence of these interactions suggested a differential response of the populations to various sowing dates. Similar results were obtained by Medeiros et al. (1995) in alfalfa, Iannucci and Martiniello (1998) in annual clover and Ranjbar (2007) in berseem clover.
The means of seed yield/plant as influenced by sowing dates and populations for 2014/2015 and 2015/2016 and over the two seasons are presented in Table 7. It is evident that the maximum seed yield/plant of 0.93 and $0.79 \mathrm{~g} / \mathrm{plant}$ was obtained the November $20^{\text {th }}$ in 2014/2015 and 2015/2016 respectively. Otherwise the minimum seed yield/plant of 0.85 and $0.57 \mathrm{~g} /$ plant were obtained when sowing date was performed at December $20^{\text {th }}$ in $2014 / 2015$ and $2015 / 2016$ seasons, respectively. It is clear results that significantly decreased as sowing date was delayed in both seasons (Table 7).

Data in Table 7, also, showed that the first sowing date was significantly higher in the average of seed yield/plant than the third sowing date in both and over the two seasons. These results may be due to that the first sowing date was the most suitable time for flowering and pollination which coincide with the activity of pollinators which play a great role in increasing seed setting by flowers tripping. These results are in line with those reported by Dobrenzo et al. (1965) and Avice et al. (1997).

Seed yield/plant over the two seasons ranged from 0.60 for Aswan to $0.93 \mathrm{~g} /$ plant for Siwa population. 
Table 7. Mean seed yield/plant for seven alfalfa varieties under each sowing dates in 2014/2015, 2015/2016 and over the two seasons.

\begin{tabular}{|c|c|c|c|c|c|c|c|c|c|}
\hline \multirow{2}{*}{ Season } & \multirow{2}{*}{ Sowing date } & \multicolumn{8}{|c|}{ Populations } \\
\hline & & Aswan & Balady & Dakhla & Ismailia & Nitro-gen Fixed & Genan & \begin{tabular}{l|l} 
Siwa 1 \\
1
\end{tabular} & Mean \\
\hline \multirow{8}{*}{$2014 / 2015$} & D1 & 0.61 & 1.10 & 0.90 & 0.84 & 0.70 & 1.15 & 1.15( & 0.92 \\
\hline & $\mathrm{D} 2$ & 0.66 & 1.25 & 0.88 & 0.79 & 0.76 & 1.09 & 1.05( & 0.93 \\
\hline & D3 & 0.47 & 0.88 & 1.15 & 0.97 & 0.69 & 0.62 & 1.15( & 0.85 \\
\hline & Mean & 0.58 & 1.08 & 0.98 & 0.87 & 0.72 & 0.96 & 1.12( & 0.90 \\
\hline & RLSD 5\% for & & & & & & & & \\
\hline & Sowing date (D) & & & & & & & & - \\
\hline & Variety $(\mathbf{V})$ & & & & & & & 0.13 & \\
\hline & VxD & & & & & & & 0.27 & \\
\hline \multirow{8}{*}{$2015 / 2016$} & D1 & 0.72 & 0.91 & 0.59 & 0.82 & 0.84 & 0.68 & 0.73 & 0.76 \\
\hline & $\mathrm{D} 2$ & 0.42 & 0.68 & 0.77 & 0.71 & 0.74 & 1.31 & 0.90 & 0.79 \\
\hline & $\overline{\mathrm{D} 3}$ & 0.68 & 0.49 & 1.06 & 0.40 & 0.47 & 0.26 & 0.63 & 0.57 \\
\hline & Mean & 0.61 & 0.69 & 0.81 & 0.65 & 0.68 & 0.75 & 0.75 & 0.71 \\
\hline & RLSD 5\% for & & & & & & & & \\
\hline & Sowing date (D) & & & & & & & 0.15 & \\
\hline & Variety (V) & & & & & & & & - \\
\hline & VXD & & & & & & & 0.31 & \\
\hline \multirow{8}{*}{$\begin{array}{l}\text { Combined } \\
\text { over } \\
\text { two seasons }\end{array}$} & $\mathrm{D} 1$ & 0.67 & 1.01 & 0.74 & 0.83 & 0.77 & 0.92 & 0.94 & 0.84 \\
\hline & $\mathrm{D} 2$ & 0.54 & 0.96 & 0.83 & 0.75 & 0.75 & 1.20 & 0.97 & 0.86 \\
\hline & D3 & 0.58 & 0.69 & 1.11 & 0.69 & 0.58 & 0.44 & 0.89 & 0.71 \\
\hline & Mean & 0.60 & 0.89 & 0.89 & 0.76 & 0.70 & 0.85 & 0.93 & 0.80 \\
\hline & RLSD 5\% for & & & & & & & & \\
\hline & \begin{tabular}{|l} 
Sowing date (D) \\
\end{tabular} & & & 0.1 & & & Y X D & & - \\
\hline & Variety (V) & & & 0.1 & & & $\mathbf{Y} \times \mathbf{V}$ & 0.19 & \\
\hline & $V \times D$ & & & 0.19 & & & YXVXD & 0.30 & \\
\hline
\end{tabular}

D1= Sowing date at $20^{\text {th }}$ October.

D3 $=$ Sowing date at $20^{\text {th }}$ December.

\section{I.5- Seed yield $/ \mathrm{m}^{2}$ (g):}

The combined analysis of variance over the two seasons showed highly significantly differences among seasons, sowing dates, and varieties respect to seed yield $/ \mathrm{m}^{2}$ (Table 3). Also, highly significant differences were found for sowing dates $\mathrm{x}$ seasons, sowing dates $\mathrm{x}$ varieties, varieties $\mathrm{x}$ seasons and sowing dates $\mathrm{x}$ varieties $\mathrm{x}$ seasons interactions. These results indicated that the response of the studied varieties un-
D2 $=$ Sowing date at $20^{\text {th }}$ November.

- F value not significant. der different sowing dates varied from season to season. This result may be due to the large differences climatic conditions prevailing in these sowing dates. The presence of these interactions suggested a differential response of varieties to varied sowing dates. Similar results were obtained by Medeiros et al. (1995).

The average seed yield $/ \mathrm{m}^{2}$ as influenced by sowing dates and varieties for 2014/2015, 2015/2016 and 
over the two seasons are presented in Table 8.

It is evident that the maximum seed yield $/ \mathrm{m}^{2}$ of 129.9 and 81.67 $\mathrm{g} / \mathrm{m}^{2}$ were obtained when planting date was performed at October $20^{\text {th }}$ in 2014/2015 and 2015/2016 seasons, respectively. Moreover, seed yield $/ \mathrm{m}^{2}$ decreased as sowing dates was delayed in both seasons (Table 8). Temperature conditions during growth, flowering, pollination and seed maturity for each sowing date were quite different and this had a significant impact on the results. For the last cut (Third cut) of the first sowing date, the growth for seed production was during first of March but pollination, fertilization and maturity of seeds occurred during the period from Mid-April to the third week of June. For the second sowing date, vegetative growth until seed maturity took place from first April until end of June. But the third sowing date, vegetative growth until seed maturity took place from $5^{\text {th }}$ May until Mid July.

Data in Table 8, also, showed that the first sowing date significantly recorded higher average of seed yield $/ \mathrm{m}^{2}$ than the other sowing dates over two seasons. The seed yield $/ \mathrm{m}^{2}$ recorded 105.6 in first sowing date compared to $73.6 \mathrm{~g} / \mathrm{m}^{2}$ in the third sowing date averaged over the two seasons.

These results suggest that first sowing date was the most suitable time for flowering and pollination which coincide with the activity of pollinators (honey bees) which play a great role in increasing seed setting by tripping the flowers. These results are in line with those reported by Dobrenzo et al. (1965) who found that the time required for flowering initiation decreased as the average minimum temperature increased. Furthermore, Medeiros et al. (1995) reported that high temperature during flowering probably limit insect pollination and enhance physiological losses of pollinated flowers and increases embryo abortion. Thus the first sowing date is more favourable for both vegetative growth and seed yield.

Data in Table 8 showed that Aswan population significantly produced the highest seed yield $/ \mathrm{m}^{2}$ as compared with the other studied varieties in first season and over the two seasons. While, in the second season, the Aswan and Balady populations significantly produced the highest seed $y i e l d / \mathrm{m}^{2}$ as compared with the other studied varieties.

Considering the significant interaction in both separate and combined analysis. The data in Table 8 indicated that Aswan population had the highest seed yield $/ \mathrm{m}^{2}$ in the first, second and over the two seasons when sown at October $20^{\text {th }}$ (first sowing date). 
Table 8. Mean seed yield $\left(\mathrm{g} / \mathrm{m}^{2}\right)$ for seven alfalfa varieties under each sowing dates in 2014/2015, 2015/2016 and over the two seasons.

\begin{tabular}{|c|c|c|c|c|c|c|c|c|c|}
\hline \multirow[b]{2}{*}{ Season } & \multirow[b]{2}{*}{ Sowing date } & \multicolumn{8}{|c|}{ Populations } \\
\hline & & Aswan & Balady & Dakhla & Ismailia & $\begin{array}{c}\text { Nitro-gen } \\
\text { Fixed }\end{array}$ & Genan & Siwa & Mean \\
\hline \multirow{8}{*}{$2014 / 2015$} & D1 & 214.00 & 152.67 & 168.00 & 122.00 & 93.67 & 56.00 & 100.00 & 129.48 \\
\hline & D2 & 190.67 & 170.00 & 224.00 & 84.33 & 88.00 & 40.00 & 64.00 & 123.0 \\
\hline & D3 & 128.00 & 104.00 & 85.00 & 109.00 & 60.00 & 46.00 & 100.33 & 90.33 \\
\hline & Mean & 177.56 & 142.22 & 159.00 & 105.11 & 80.56 & 47.33 & 88.11 & 114.27 \\
\hline & RLSD 5\% for & & & & & & & & \\
\hline & Sowing date (D) & & & & & & & & 25.17 \\
\hline & Variety (V) & & & & & & & & 14.68 \\
\hline & V $x D$ & & & & & & & & 27.0 \\
\hline \multirow{8}{*}{$2015 / 2016$} & $\mathrm{D} 1$ & 128.00 & 90.67 & 75.00 & 90.33 & 53.67 & 47.33 & 86.67 & 81.67 \\
\hline & D2 & 53.11 & 102.42 & 75.38 & 42.86 & 53.11 & 59.84 & 65.72 & 64.64 \\
\hline & D3 & 95.24 & 86.29 & 54.70 & 37.08 & 35.54 & 58.00 & 31.45 & 56.90 \\
\hline & Mean & 92.12 & 93.13 & 68.36 & 56.76 & 47.44 & 55.06 & 61.28 & 67.73 \\
\hline & RLSD 5\% for & & & & & & & & \\
\hline & \begin{tabular}{|l} 
Sowing date (D) \\
\end{tabular} & & & & & & & & 6.13 \\
\hline & Variety (V) & & & & & & & & 2.79 \\
\hline & V X D & & & & & & & & 4.83 \\
\hline \multirow{8}{*}{$\begin{array}{c}\text { Combined } \\
\text { over two } \\
\text { seasons }\end{array}$} & D1 & 171.00 & 121.67 & 121.50 & 106.17 & 73.67 & 51.67 & 93.33 & 105.57 \\
\hline & D2 & 121.89 & 136.21 & 149.69 & 63.60 & 70.56 & 49.92 & 64.86 & 93.82 \\
\hline & D3 & 111.62 & 95.15 & 69.85 & 73.04 & 47.77 & 52.00 & 65.89 & 73.62 \\
\hline & Mean & 134.84 & 117.67 & 113.68 & 80.93 & 64.00 & 51.20 & 74.70 & 91.00 \\
\hline & RLSD 5\% for & & & & & & & & \\
\hline & Sowing date (D) & & & 7.62 & & & Y X D & & 11.06 \\
\hline & Variety $(\mathrm{V})$ & & & 7.28 & & & $Y \times V$ & & 10.29 \\
\hline & VXD & & & 13.13 & & & YxVxD & & 18.65 \\
\hline
\end{tabular}

D1 $=$ Sowing date at $20^{\text {th }}$ October.

D2= Sowing date at $20^{\text {th }}$ November.

D3 $=$ Sowing date at $20^{\text {th }}$ December.

II- Stability analysis for seed yield and its components

The analysis of variance across populations and environments indicated that the environments, populations and populations $\mathrm{x}$ environments (GE) interactions were highly significant for all studied traits (Table 9). The environment and population $\mathrm{x}$ environment mean squares were significant indicating that the three sowing dates in the two seasons provided a sufficient range of environments, and hence the validating of environmental requirements suggested by Tai (1971) were fulfilled for number of pods/plant, number of seeds/pod, seed index and seed yield/plant and seed $y i e l d / \mathrm{m}^{2}$. The results are in broad agreement with Bakheit et al. (2012) and, Mohamed, Asmaa et al. (2017) in Egyptian clover, Hill and Baylor (1983) and Bolanos-Aguilar (2002) in alfalfa.

\section{II.1- Number of pods/plant}

The mean number of pods/plant and stability parameters ( $\alpha$ and $\lambda$ ) of the different populations over the six environments (three sowing dates $\mathrm{x}$ two seasons) are presented in Table 10, and graphically plotted in Fig. 1a. The mean number of pods/plant ranged from 52.87 for Aswan population to 68.0 for Siwa population. On 
the other hand, Siwa population was significantly higher than the Aswan, Balady, Nitrogen fixed and Genan populations in number of pods/plant.

The data in Table 10 revealed that the populations greatly differed in the amount of deviation from the linear response $(\lambda)$ and to a less extent in the linear response $(\alpha)$. All populations except Ismailia population had significant $\lambda$ values. Siwa population followed by Nitrogen fixed and Dakhla populations had the highest $\lambda$ values, therefore, they were unstable. The distribution of $\alpha$ and $\lambda$ values (Fig. 1a) indicated that all populations were located in the area out of stability region.

\section{II.2- Number of seeds/pod}

The mean number of seeds/pod for populations are shown in Table 10. It ranged from 4.58 for Aswan population to 6.45 for Dakhla population. The population of Balady, Dakhla, and Genan were higher than the rest. It is worth to mention that those three populations significantly exceeded the populations of Aswan, Ismailia, and Nitrogen fixed.

The data in Table 10 revealed that the populations differed greatly in the amount of deviation from the linear response $(\lambda)$ and to a less extent in the linear response $(\alpha)$. Populations of Aswan, Dakhla, Genan and Siwa had significant $\lambda$ values. Genan population followed by Aswan and Siwa populations had the highest $\lambda$ values, therefore, they were unstable.

The distribution of $\alpha$ and $\lambda$ values (Fig. 1b) indicated that the stability area contained three out of seven populations Ismailia, Balady and Nitrogen fixed populations were the most stable ones. Also, Dakhla popu- lation was near of stability region. The other populations were located in the area out of stability region.

The Genan population has significant $\lambda$ value and has high number of seed/pod, therefore, it was unstable. The Balady population was distributed in the average stability region and showed high number of seeds/pod. It can be used as a source of number of seeds/pod improvement in breeding programmes.

\section{II.3- Seed index (1000 seed weight, g)}

Mean seed index and stability parameters of the different populations over the six environments are presented in Table 10 and graphically plotted in Fig. 1c. Mean seed index ranged from $2.29 \mathrm{~g}$ for Genan population to $2.62 \mathrm{~g}$ for Aswan population. The Aswan population was heavier than the rest populations. It is worth to mention that Aswan population only significantly exceeded the other populations except Balady population.

The data in Table 10 revealed that the populations differed greatly in the amount of deviation from the linear response $(\lambda)$ and to a less extent in the linear response $(\alpha)$. Aswan and Dakhla populations had significant $\lambda$ values. Aswan population followed by Dakhla population had the highest $\lambda$ values, therefore, they were unstable.

The distribution of $\alpha$ and $\lambda$ values (Fig. 1c) indicated that the stability area contained one out of the seven populations Ismailia population was the most stable one, but the other populations (Aswan, Balady, Dakhla, Nitrogen fixed, Genan and Siwa) were unstable. The Aswan and Bal- 
ady populations had significant $\lambda$ values and high in seed index, therefore, they were unstable. The Ismailia population was distributed in the average stability region and showed good seed index, thereby can be used as a source of seed index improvement in breeding programmes.

\section{II.4- Seed yield/plant and seed yield $/ \mathrm{m}^{2}$ (g)}

Seed yield/plant and seed yield $/ \mathrm{m}^{2}$ for the seven populations over all environment ranged from 0.60 to $0.93 \mathrm{~g} /$ plant, and from 51.2 to $134.8 \mathrm{~g} / \mathrm{m}^{2}$ respectively, (Table 10 ). The lowest population in seed yield was Genan population. The superior population in seed yield was Aswan population which significantly outyielded all the other populations.

The populations differed greatly in the amount of deviation from the linear response ( $\lambda$ values) and to a less in the linear response ( $\lambda$ values) for each of seed yield/plant and seed yield $/ \mathrm{m}^{2}$ (Table 10 ). The great variation in the estimates suggested that the relatively unpredictable component of the varieties $x$ environment interaction variance may be more important than the relatively predictable component of variation for those varieties. Moreover, the varieties showed different degrees of stability. Similar conclusions were reached by Bakheit (1985) in Egyptian clover, Bakheit (1988) in alfalfa and Mohamed, Asmaa et al. (2017) in Egyptian clover.

All varieties except Nitrogen fixed and Genan populations for seed yield $/ \mathrm{m}^{2}$ had significant $\lambda$ values. But for seed yield/plant only Aswan and Dakhla population had significant $\lambda$ values. Some of those populations viz. Aswan and Dakhla populations were high in seed yield, but they were unstable.

The average stability area for seed yield/plant (Fig. 1c) contained five out of the seven populations. On the other hand, two populations, Aswan and Dakhla were out of stability area. While, the average stability area for seed yield $/ \mathrm{m}^{2}$ contained only Nitrogen fixed population (Fig. 1d). The highest seed yielding populations were unstable. It is worth to mention that the Nitrogen fixed and Genan populations which were below the average in yield showed nearly stability region.

For practical utility of the obtained results, there are different choices; it may be possible to select a high seed yielding population which shows relatively low level of stability such as Balady population (seed yield $/ \mathrm{m}^{2}=117.7 \mathrm{~g}, \alpha=0.07$ and $\lambda=$ $\left.4.57^{*}\right)$ as a source of high seed yielding genes to be crossed with the below average seed yielding population such as population Nitrogen fixed (seed yield $=64.0 \mathrm{~g} / \mathrm{m}^{2}$ ) and which exhibited stability $(\alpha=-0.28$, and $\lambda=$ $0.44)$. Therefore, selection should be practiced for a population with high yielding ability and average stability as some investigators reported that stability index is a heritable trait (Finley, 1971 and Jewett, 1972). 
Table 9. Stability analysis of variance for seed yield and its components of seven alfalfa varieties under different environments.

\begin{tabular}{|c|c|c|c|c|c|c|}
\hline \multirow[b]{2}{*}{$\begin{array}{c}\text { Source of } \\
\text { variation }\end{array}$} & \multirow[b]{2}{*}{ d.f } & \multicolumn{5}{|c|}{ Mean Square for } \\
\hline & & $\begin{array}{l}\text { Number of } \\
\text { pods/plant }\end{array}$ & $\begin{array}{l}\text { Number of } \\
\text { seeds/pod }\end{array}$ & Seed index & $\begin{array}{c}\text { Seed } \\
\text { yield/plant } \\
\text { (g) }\end{array}$ & $\begin{array}{c}\text { Seed } \\
\text { yield } \\
\left(\mathrm{g} / \mathbf{m}^{2}\right)\end{array}$ \\
\hline Environment (E) & 5 & $839.4 * *$ & $24.96 * *$ & $4.7 * *$ & $0.38 * *$ & $18689.1 * *$ \\
\hline Rep./Env. & 12 & 58.06 & 0.72 & 0.033 & 0.033 & 649 \\
\hline Varieties (V) & 6 & $475.7 * *$ & $8.65 * *$ & $0.33 * *$ & $0.26^{* *}$ & $17484.7 * *$ \\
\hline $\mathbf{V} \times \mathbf{E}$ & 30 & $479.97 * *$ & $3.83 * *$ & $0.26^{* *}$ & $0.14 * *$ & $2732.8 * *$ \\
\hline Error & 72 & 67.11 & 0.84 & 0.03 & 0.03 & 155.73 \\
\hline
\end{tabular}

** Significant at 0.01 level of probability.

Table 10. Mean performance over six environment $(\bar{X})$ and stability parameter $(\alpha, \lambda)$ of seven alfalfa varieties for number of pods/plant, number of seeds/pod, seed yield/plant, seed yield $/ \mathbf{m}^{2}$, seed index.

\begin{tabular}{|c|c|c|c|c|c|c|c|c|c|c|c|c|c|c|c|}
\hline & \multicolumn{3}{|c|}{ Number of pods/plant } & \multicolumn{3}{|c|}{ Number of seeds/pod } & \multicolumn{3}{|c|}{ Seed Index (g) } & \multicolumn{3}{|c|}{ Seed yield/plant (g) } & \multicolumn{3}{|c|}{ Seed yield $/ \mathbf{m}^{2}(\mathrm{~g})$} \\
\hline & $\mathrm{X}$ & $\alpha$ & $\lambda$ & X & $\boldsymbol{\alpha}$ & $\lambda$ & $\bar{X}$ & $\alpha$ & $\lambda$ & X & $\boldsymbol{\alpha}$ & $\lambda$ & $\bar{X}$ & $\boldsymbol{\alpha}$ & $\lambda$ \\
\hline Aswan & 52.97 & -0.99 & $2.88^{*}$ & 4.58 & -0.19 & $7.47^{*}$ & 2.62 & -0.18 & $15.57 *$ & 0.85 & 1.34 & $8.3^{*}$ & 134.8 & 0.92 & $7.73^{*}$ \\
\hline Balady & 57.44 & 0.33 & $2.55^{*}$ & 6.06 & -0.26 & $1.07 *$ & 2.53 & 0.01 & $8.97 *$ & 0.89 & 0.94 & 1.63 & 117.67 & 0.07 & $4.57^{*}$ \\
\hline Dakhla & 64.8 & -2.37 & $5.97 *$ & 6.45 & 0.26 & $2.58^{*}$ & 2.24 & -0.13 & $5.32 *$ & 0.89 & -1.25 & $4.52^{*}$ & 113.68 & 1.06 & $17.65^{*}$ \\
\hline Ismailia & 63.88 & 0.95 & $0.22 *$ & 5.06 & -0.02 & $2.23^{*}$ & 2.41 & -0.07 & $1.83 *$ & 0.76 & 0.19 & 1.54 & 80.93 & -0.09 & $9.90 *$ \\
\hline Fixed & 61.31 & 0.26 & $5.98^{*}$ & 5.31 & 0.31 & $0.96^{*}$ & 2.33 & 0.09 & $12.43 *$ & 0.7 & -0.42 & 1.06 & 64.00 & -0.28 & $0.44 *$ \\
\hline Genan & 58.14 & 1.4 & $2.70^{*}$ & 6.27 & -0.34 & $9.00^{*}$ & 2.29 & 0.07 & $3.01^{*}$ & 0.60 & -1.34 & 1.32 & 51.2 & -1.17 & $0.12^{*}$ \\
\hline Siwa & 68.67 & 0.42 & $10.76^{*}$ & 5.95 & 0.24 & $6.64 *$ & 2.44 & 0.21 & $11.18^{*}$ & 0.93 & 0.55 & 1.12 & 74.7 & -0.52 & $10.63^{*}$ \\
\hline R.L.S.D. & 5.2 & & & 0.56 & & & 0.11 & & & 0.1 & & & 7.28 & & \\
\hline
\end{tabular}

$* \lambda$ value greater than $F$ value derived from $F$ table with $n_{1}=4, n_{2}=72$ and $a=0.05$ 


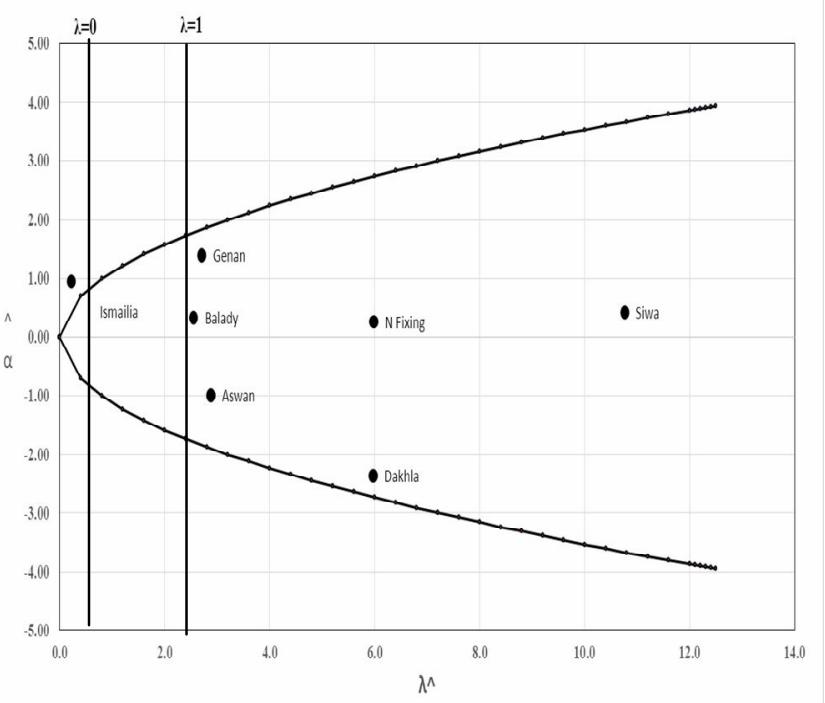

a- Number of pods/plant

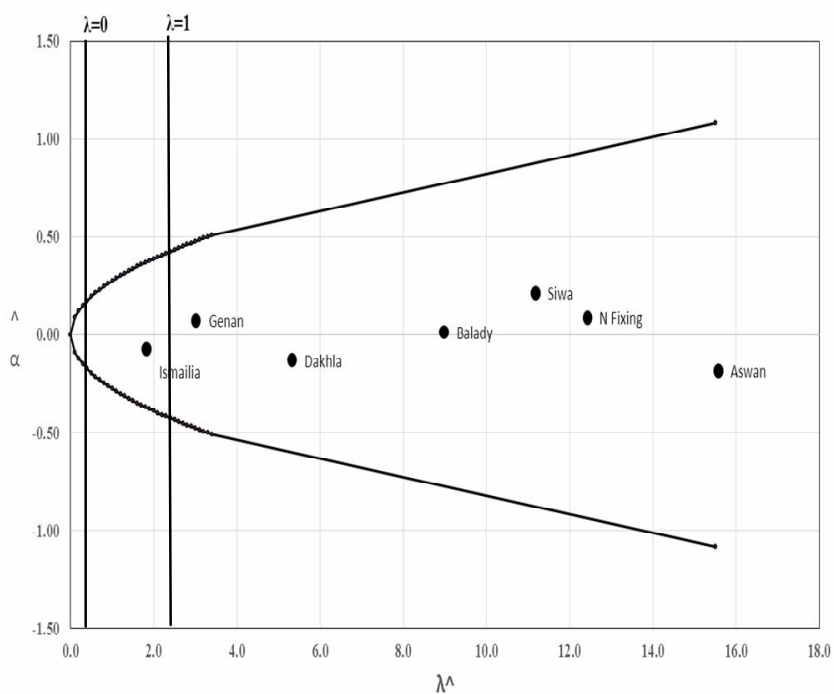

c- Seed index

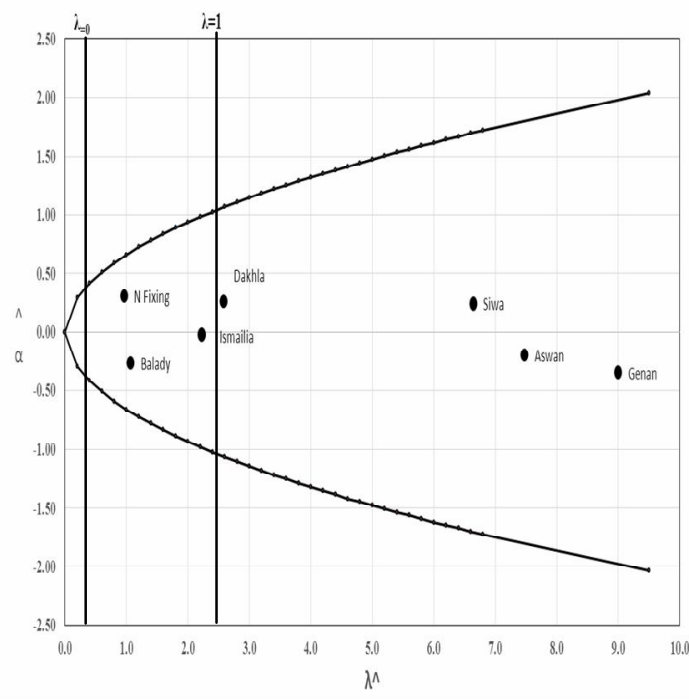

b- number of seeds/pod

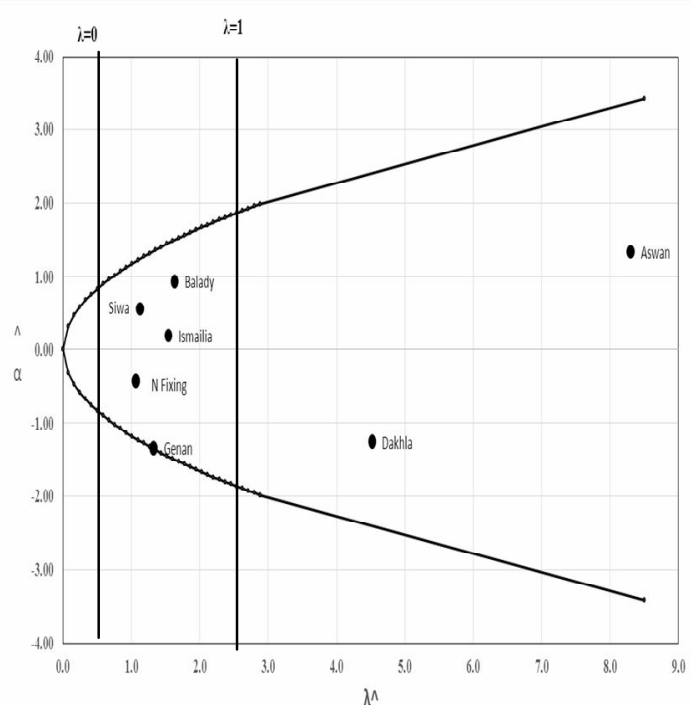

d- Seed vield/plant

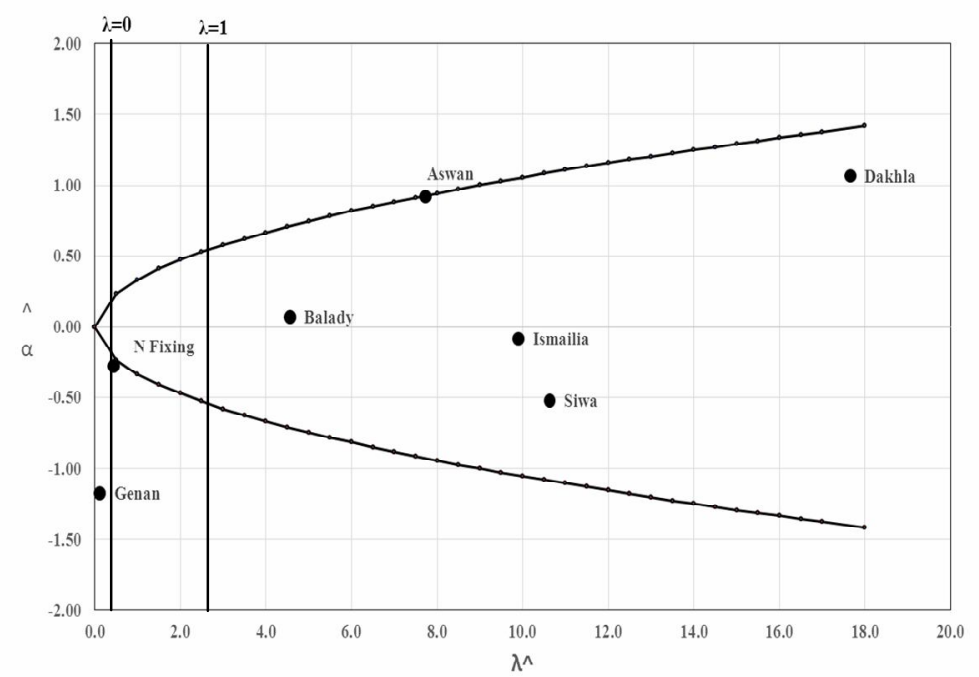

e- Seed yield $/ \mathrm{m}^{2}$

Fig. 1. Distribution estimates of genotypic stability parameter for of seven alfalfa varieties. 
Furthermore, it could also be noticed that the Ismailia population had number of pods/plant, number of seeds/pod and seed index of 63.8, 5.06 and 2.41, respectively. In addition, this population was distributed in the average stability region for these traits. Such population may be used as high number of pods/plant, number of seeds/pod and seed index donor. Also, it was detected that Balady population had high seed yield and near to stability region, in addition it is high for number of pods/plant and number of seed/pod which were located in the stability region for these trait. Thus, this population could be advise for commercial alfalfa production in Egypt.

\section{References}

Avice, J.C.; G. Laemaire; A. Ourry and J. Boucaud (1997). Effects of the previous shoot removal frequency on subsequent shoot regrowth in two Medicago sativa L. cultivars. Plant Soil, 188: 189-196.

Bakheit, B.R. (1985). Genotypic stability of some multicut Egyptian clover (Trifolium alexandrinum L.) genotypes. Assiut J. Agric. Sci., 16: 2137.

Bakheit, B.R. (1988). Variation, correlation and path-coefficient analysis in some world varieties of alfalfa (Medicago sativa L.). Assiut J. Agric. Sci., 19: 149-163.

Bakheit, B.R., M.A. Ali and A.A. Helmy (2012). The influence of temperature, genotype and genotype $\mathrm{x}$ temperature interaction on seed yield of berseem clover (Trifolium alexandrium L.). Asian J. Plant Sci., 4: 63-71.

Bolaños-Aguilar, E.D.; C. Huyghe; D. Djukic; C. Ecalle and B. Julier (2002). Effect of cultivar and envi- ronment on seed yield in alfalfa. Crop Science, 42: 45-50.

Dobrenzo, A.K.; M.A. Massengale and W.S. Phillips (1965). Floral initiation in alfalfa (Medicago sativa L.). Crop Sci., 5: 572-575.

Finley, K.W. (1971). Breeding for yield in barley. Intn., Barley Genet. Symp. Proc., 2: 345-388.

Ghanizadeh, N.; A. Moghaddam and N. Khodabandeh (2014). Comparing the yield of alfalfa cultivars in different harvests under limited irrigation condition. International Journal of Biosciences, 4: 131-138.

Gomez, K.A. and A.A. Gomez (1984). Statistical Procedures for Agricultural Research. Jon Wiley and Sons, New York, $2^{\text {nd }}$ ed.

Hill, Jr. R.R. and J.E. Davior (1983). Genotype $\mathrm{x}$ environment interaction analysis for yield in alfalfa. Crop Sci., 23: 811-815.

Huyghe, C.; B. Julier; E.O. BolanosAguilar; C. Ecalle and J. Hacquet (2001). Effect of cultivar and environment on seed yield in alfalfa. Options Mediterraneennes, 127130.

Iannucci, A. and P. Martiniello (1998). Analysis of seed yield components in four Mediterranean annual clovers. Field Crops Res., 55: 235-243.

Jewett, D. (1972). Yield stability parameters for sorghum in East Africa. Crop Sci., 12: 314-317.

Kowithayakorn, H. and M.J. Hill (1982). A study of seed production of Lucerne (Medicago sativa L.) under different plant spacing and cutting treatments in the seeding year. Seed Science and Technology 10, 3-12.

Martiniello, P.; A. Iannucci; A. Felicioli and M. Pinzauti (1999). Ethological behaviours of solitary pollinators and their effect on berseem and alfalfa seed yield and seed 
yield components in Mediterranean environment. Proceedings of the $4^{\text {th }}$ International Herbage Seed Conference, May 23-27, 1999, Perugia, Italy, pp: 106-110.

Medeiros, R.B., A.V.A. Jacques and C. Nabinger (1995). Alfalfa (Medicago sativa L.) seed production under different row spacing and plant population in the seeding year. Proceedings of the $3^{\text {rd }}$ International Herbage Seed Conference, June 18-23, 1995, Halle (Saale), Germany, pp: 331-335.

Mohamed, A. Asmaa; B.R. Bakheit; E.A. Teama and F.M. Fathy (2017). Effect of planting date, variety and their interaction on seed yield and its components of Egyptian clover (Trifolium alexandrinum L.). Assiut J. Agric. Sci., 48: 1-11.

Ranjbar, G.A. (2007). Forage and hay yield performance of different berseem clover (Trifolium alexnadrinum L.) genotypes in mazadaran conditons. Asian J. Plant Sci., 6: 1006-2011.

Rezaei, M.; R.M. Amiri; M.R. Naghavi; R. Mohammadi and M.M. Kaboli (2010). Evaluation of phenotypic diversity in ecotypes of alfalfa (Medicago sativa) from Iran. Iranian Journal of Field Crop Science, 41: 123-129.

Saeed, M. and C.A. Francis (1984). Association of weather variables with genotype $\mathrm{x}$ environment interaction in grain sorghum. Crop Sci., 24: 13-16.

Sengul, S. (2006). Using path analysis to determine Lucerne (Medicago sativa L.) seed yield and its components. New Zealand Journal of Agricultural Research, 49: 107-115.

Tai, G.C.C. (1971). Genotypic stability analysis and its application to potato regional trials. Crop Sci., 11: 184-190. 
ثبات المحصول البذري ومكوناته لبعض التراكيب الوراثية للبرسيم الحجازي تحت اختلاف البيئة

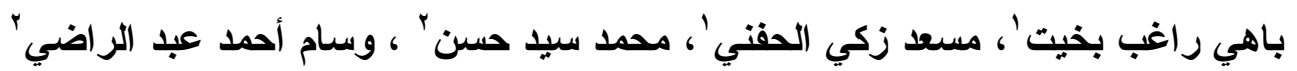

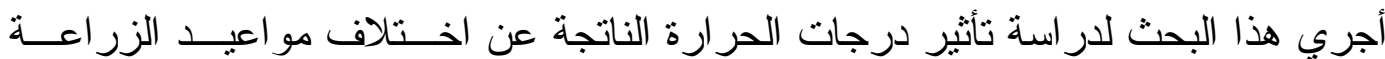

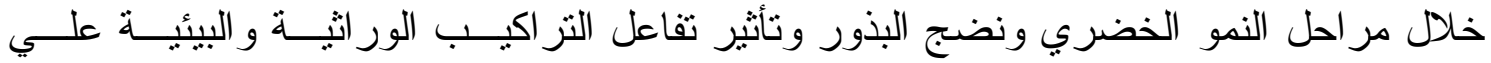

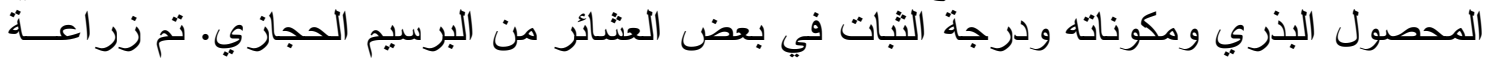

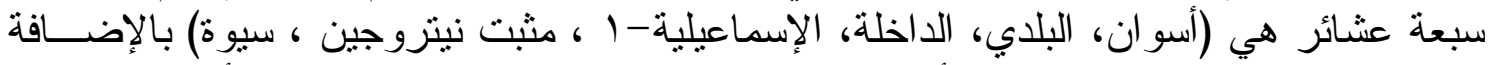

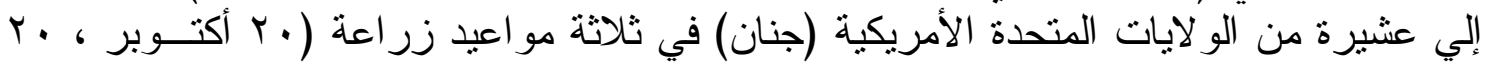

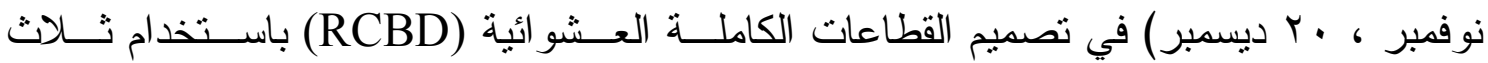

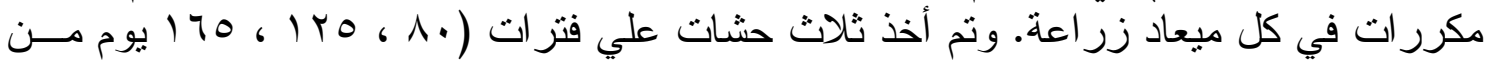

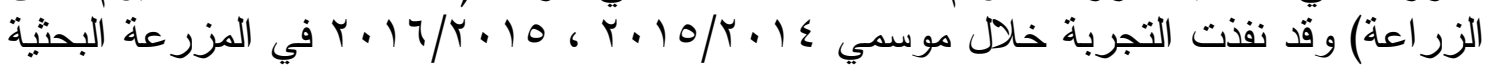
لكلية الزر اعة جامعة جنوب الو ادي بمحافظة قنا.

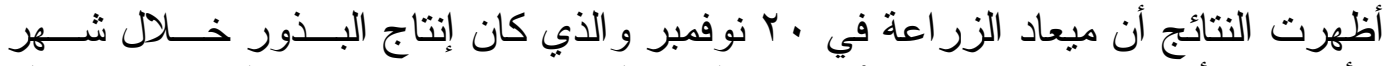

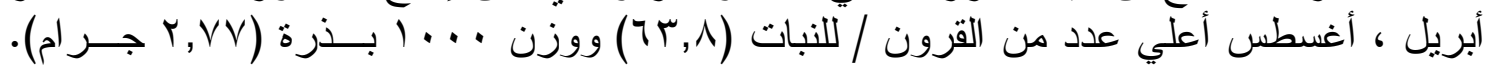

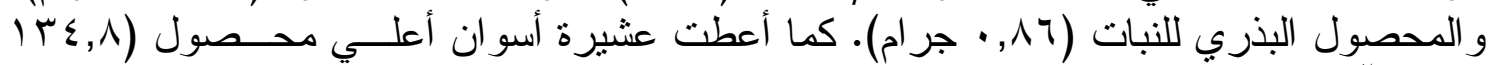

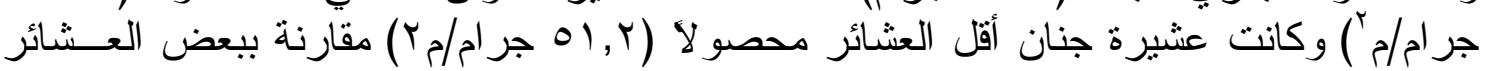

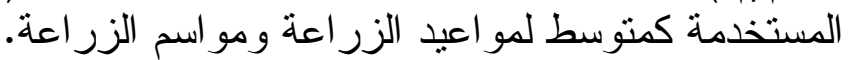

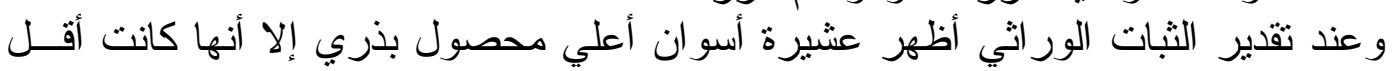

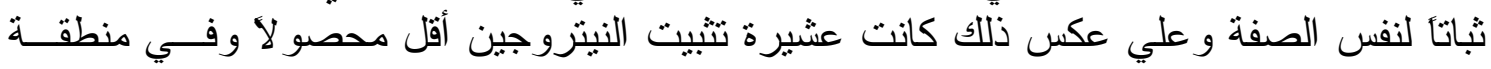

